DOI https://doi.org/10.18551/rjoas.2021-01.17

\title{
ECONOMIC PERFORMANCE OF LOCAL BREEDER PATTERNS FOR BALI CATTLE FATTENING GIVEN CONCENTRATE FEED CONTAINING BANANA CORM AND Zn- BIOCOMPLEX ADDITIVES
}

\author{
Sobang Yohanis U.L., Marthen Y., Tenang \\ Department of Animal Husbandry, Nusa Cendana University, Indonesia
}

Paulus C.A.*

Department of Aquatic Resource Management, Nusa Cendana University, Indonesia

\author{
*E-mail: chatepaulus@undana.ac.id \\ ORCID: 0000-0001-8507-3599
}

\begin{abstract}
This study aims to determine the effect of concentrated feed containing fermented banana corm meal at different levels with Zn-biocomplex additives on the economic performance of Bali cattle fattening. The research object are four male Bali cattle aged 1.5-2 years at a weight range of $135-164.5$ with an average of $144.75 \mathrm{~kg}$. This study used an experimental method with a Latin square design consisting of 4 treatments and 4 periods as replications. The treatments in this study were (1) $\mathrm{P}_{0}$; farmer pattern feed $+1 \mathrm{~kg}$ concentrate feed without fermented banana corm, (2) $P_{1}$; farmer pattern feed $+1 \mathrm{~kg}$ concentrate feed containing $20 \%$ fermented banana corm, (3) $\mathrm{P}_{2}$; farmer pattern feed $+1 \mathrm{~kg}$ concentrate feed containing $40 \%$ fermented banana corm, and (4) $\mathrm{P}_{3}$; farmer pattern feed $+1 \mathrm{~kg}$ concentrate feed containing $60 \%$ fermented banana corm. The data obtained were analyzed using Analysis of Variance (ANOVA). The average production costs (IDR): $P_{0}$ 5833750 $\pm 71107.31, P_{1}$ $5523750 \pm 87118.21, \mathrm{P}_{2} 5375000 \pm 88975.65, \mathrm{P}_{3}$ 5168750 \pm 55433.89 ; Income average (IDR): $P_{0} \quad 1017500 \pm 82209.08, \quad P_{1} \quad 1477500 \pm 233862.49, \quad P_{2} \quad 2143750 \pm 139006.89, \quad P_{3}$ 2245000 \pm 1190000 ; Average feed costs (IDR): $P_{0} 751250 \pm 191588.75, P_{1} 723750 \pm 68965.57$, $\mathrm{P}_{2}$ 68965.57 $\pm 88975.65, \mathrm{P}_{3} 418750 \pm 55433.89$; IOFC average (IDR): $\mathrm{P}_{0} 266250 \pm 169576.67$, $P_{1} 753750 \pm 264303.33, P_{2} 1518750 \pm 216386.03, P_{3} 1826250 \pm 201054.51$; and $B C R$ average (IDR): $P_{0} 1.17 \pm 0.01, P_{1} 1.27 \pm 0.05, P_{2} 1.40 \pm 0.03, P_{3} 1.43 \pm 0.04$. The results of statistical analysis showed that the provision of concentrate feed containing fermented banana corm meal at different levels with $\mathrm{Zn}$-biocomplex additive very significant affected $\mathrm{P}<0.01$ on the economic performance of Bali cattle fattening.
\end{abstract}

\section{KEY WORDS}

Bali cattle fattening, concentrate, production performance, fermented banana corm, $\mathrm{Zn}$ bio complex.

The Balinese cattle rearing system in East Nusa Tenggara province (ENT) is semiintensive by relying on feed on natural grazing land and cultivated feed, especially forage and tree legumes, but feed by breeders on the island of Timor is still below the dry matter requirement for beef cattle, which only ranges $3-4 \mathrm{~kg} /$ cattle/day, whereas the dry matter requirement for beef cattle to achieve optimal growth ranges from $6-7 \mathrm{~kg} / \mathrm{cattle} /$ day. The balance of food substances, especially between protein and energy, is not optimal with a ratio of 1: 4.2, whereas in order to achieve optimal growth, a PE ratio of 1: 5.1 must be achieved (Sobang, 2005).

One of the local feeds that are always available and able to adapt to climatic conditions in ENT is banana (Musa paradisiaca). Banana corm have a fairly good nutritional value, however the corms or tubers and stems of bananas have not been optimally utilized by the community as animal feed (Fattah et al., 2019; Sobang et al, 2020). According to Rosdiana (2009) banana corm have a composition consisting of $76 \%$ starch and $20 \%$ water. Metabolic energy of $2450 \mathrm{kcal} / \mathrm{kg}$ and protein $3.4 \%$ (Munadjim, 1980), also contains antinutrients such 
as tannins, sterols, glycosides, quinones and terpenoids, polyphenols, alkaloids (Venkatesh et al., 2013).

Animal husbandry development is part of national development, so in achieving this goal, the implementation of livestock development must be able to directly address the needs of rural breeders (Paulus et al., 2018; Paulus et al., 2019; Paulus et al., 2020; Sobang et al., 2020). Development that is able to touch directly is development that is able to increase the income of breeders through the beef cattle business. Beef cattle are one of the livestock whose main production is meat, bones and skin.

In the context of developing cattle, the role of breeders in managing the environment, stables and fodder in the village cannot be ignored and instead must be fostered and supported by the government through the development of livestock projects. Beef cattle have good development prospects, especially in Oeletsala village, Taibenu district, Kupang regency. From a socio-cultural point of view, cattle are one of the sacrificial animals in various traditional ceremonies. By raising livestock, breeders can pay for family needs other than food, such as sending their children to school, health and housing. The function of livestock can also be used as family savings to meet urgent needs. This means that the success of developing the livestock sub-sector is in the hands of breeders in developing their business in order to increase their income.

One of the factors determining the success of a business is the pattern of maintenance. The maintenance pattern can certainly have its own consequences, especially in the management of inputs which have an impact on the efficiency of their use. The use of inputs will greatly affect the costs incurred by farmers, which in turn will affect their income and also their cost efficiency, both in the short and long term.

The profit that will be obtained by the farmer will be clearly seen, that the maintenance of beef cattle can be calculated based on the amount of maintenance and the number of livestock sold. Cost incurred by beef cattle breeders will be in accordance with the number of livestock raised. This causes the beef cattle business in farmer groups with economic calculations, which are based on the scale of maintenance of the profit value will be different. Therefore, this study aims to determine the economic performance of fattening Bali cows given concentrate feed supplementation containing fermented banana corm meal at different levels with Zn-biocomplex additives.

\section{METHODS OF RESEARCH}

Location and time of research. This research was conducted in Oeletsala village, Taibenu district, Kupang regency, East Nusa Tenggara province for 20 weeks, divided into 4 weeks of adjustment period and 16 weeks of data collection. Livestock of 4 male Bali cows at the age range of 2 years with a body weight range of $135-164.5 \mathrm{~kg}$ with an average of 144.75 $\mathrm{kg}$ were used in this study. The feed ingredients used are local breeders' pattern feed and complete feed. The composition of the feed ingredients for the concentrate, the nutritional content of the treatment rations are presented in Table 2, while the consumption and digestibility of the rations are in Tables 3 and 4.

Types and Sources of Data. The types of data used in this research are quantitative data and qualitative data. Quantitative data is in the form of numbers or figures related to research, while qualitative data is in the form of quantitative data by scaling. Sources of data used in this study are primary data and secondary data. Primary data is obtained from direct observation, while secondary data is obtained from various sources of literature and agencies related to research.

Research methods. The research method used is an experimental method, using a latin square design (LSD) with 4 treatments and 4 periods as replications. The treatments in this study are:

- $\mathrm{P}_{0}$ : Farmer pattern diet $+1 \mathrm{~kg}$ concentrate feed without fermented banana corm meal $+100 \mathrm{mg}$ Zn-biocomplex;

- $\quad P_{1}$ : Farmer pattern feed $+1 \mathrm{~kg}$ concentrate feed containing $20 \%$ fermented banana corm meal + 100mg Zn-biocomplex; 
- $\mathrm{P}_{2}$ : Farmer pattern feed $+1 \mathrm{~kg}$ concentrate feed containing $40 \%$ fermented banana corm meal + 100mg Zn-biocomplex;

- $\mathrm{P}_{3}$ : Farmer pattern feed $+1 \mathrm{~kg}$ concentrate feed containing $60 \%$ fermented banana corm meal $+100 \mathrm{mg}$ Zn-biocomplex.

The composition of the constituent feed ingredients and nutritional content of treatment rations can be seen in Table 1 and Table 2.

Table 1 - Composition of feed ingredients for treatment rations

\begin{tabular}{|c|c|c|c|c|}
\hline Feed Materials (\%) & $\mathrm{P}_{0}$ & $\mathrm{P}_{1}$ & $\mathrm{P}_{2}$ & $\mathrm{P}_{3}$ \\
\hline Rice bran & 40 & 30 & 20 & 10 \\
\hline Milled corn & 30 & 20 & 10 & 0 \\
\hline Fish flour & 5 & 5 & 5 & 5 \\
\hline Gamal leaf meal & 17.5 & 17.5 & 17.5 & 17.5 \\
\hline Fermented banana corm meal & 0 & 20 & 40 & 60 \\
\hline Salt & 4 & 4 & 4 & 4 \\
\hline Urea & 3 & 3 & 3 & 3 \\
\hline Starbio & 0.5 & 0.5 & 0.5 & 0.5 \\
\hline Total & 100 & 100 & 100 & 100 \\
\hline
\end{tabular}

Source: Composition of the author's simulation results (2020)

Table 2 - Nutritional content of research rations

\begin{tabular}{|c|c|c|c|c|c|c|c|c|c|}
\hline \multirow{2}{*}{ Code } & \multirow[b]{2}{*}{$\% B K$} & \multirow{2}{*}{$\begin{array}{l}\mathrm{BO} \\
(\% \mathrm{BK})\end{array}$} & \multirow{2}{*}{$\begin{array}{l}\mathrm{PK} \\
(\% \mathrm{BK})\end{array}$} & \multirow{2}{*}{$\begin{array}{l}\text { LK } \\
(\% B K)\end{array}$} & \multirow{2}{*}{$\begin{array}{l}\mathrm{SK} \\
(\% \mathrm{BK})\end{array}$} & \multirow{2}{*}{$\begin{array}{l}\mathrm{CHO} \\
(\% \mathrm{BK})\end{array}$} & \multirow{2}{*}{$\begin{array}{l}\text { BETN } \\
(\% B K)\end{array}$} & \multicolumn{2}{|l|}{ Energy } \\
\hline & & & & & & & & $\mathrm{MJ} / \mathrm{kg} \mathrm{BK}$ & Kkal/kg BK \\
\hline Lamtoro & 30.62 & 83.55 & 23.27 & 3.52 & 14.81 & 56.76 & 41.95 & 16.66 & $3,966.74$ \\
\hline Kabesak & 23.12 & 80.94 & 15.40 & 3.46 & 26.74 & 62.08 & 35.34 & 15.65 & $3,726.85$ \\
\hline Nunuk & 25.78 & 75.56 & 12.55 & 3.40 & 22.17 & 59.61 & 37.44 & 14.51 & $3,455.77$ \\
\hline K. PO & 81.52 & 80.31 & 15.76 & 4.06 & 14.36 & 58.49 & 44.13 & 16.01 & $3,810.94$ \\
\hline K. P1 & 82.27 & 81.84 & 17.09 & 4.42 & 13.68 & 58.33 & 44.65 & 16.42 & $3,910.34$ \\
\hline K. P2 & 82.75 & 81.36 & 17.84 & 4.29 & 13.26 & 57.23 & 43.97 & 16.37 & $3,897.75$ \\
\hline K. P3 & 81.02 & 80.22 & 16.36 & 4.14 & 13.67 & 57.72 & 44.05 & 16.05 & $3,820.35$ \\
\hline TBP & 75.36 & 73.08 & 3.89 & 0.84 & 18.16 & 68.35 & 50.19 & 13.05 & $3,108.08$ \\
\hline TBPF & 81.24 & 79.66 & 10.72 & 1.04 & 16.52 & 67.90 & 51.38 & 14.70 & $3,499.93$ \\
\hline
\end{tabular}

Source: Laboratory results of Animal Nutrition Analysis of IPB University (2020).

Method of collecting data. The data used in this study consisted of primary data and secondary data, both qualitative and quantitative data. Primary data is obtained through direct observation, while secondary data is obtained through notes or historical records that have been arranged in archives or documents obtained from agencies and various sources of literature related to this research.

Measured parameters. The parameters measured are as follows:

Cost. Cost is the basis for determining prices, because a price level that cannot cover costs will result in losses. Conversely, if a price level exceeds all costs, both production costs, operational costs and non-operating costs, it will generate profits.

Income. Income is the difference between revenue and expenses. This parameter is calculated according to the instructions Soekartawi (2003) with the formula:

$$
\begin{gathered}
\text { Income }=\text { Total revenue }- \text { Total expenses } \\
\text { Profit }=\text { Income }- \text { Total cost }
\end{gathered}
$$

Feed cost. Feed costs cover $70-80 \%$ of total production costs. The cost of feed can be determined by the following formula:

$$
\text { Feed cost }=\text { Total ration consumptiion } x \text { Ration price }
$$

Income Over Feed Cost (IOFC). Income Over Feed Cost is an important variable that can economically describe the amount of profit obtained from each treatment. According to Bailey et al., (2009), IOFC can be calculated using the formula:

$$
I O F C=B B H S(I D R / K g) \times P B B H(K g)-B P H(I D R / \text { cow })
$$


Where: IOFC: Income over feed cost (IDR/cow/day); BBHS: Cattle live weight cost (IDR/Kg); PBBH: Daily weight gain (Kg); BPH: Daily feed cost (IDR/cow).

Benefit Cost Ratio (BCR). Benefit Cost Ratio (BCR) is the ratio between the level of profit earned and the total costs incurred. A business is said to be feasible and provides benefits if the value of $B C R$ is $>1$. The greater the value of $B C R$, the greater the benefits that will be obtained from the business.

$$
\mathrm{BCR}=\frac{\text { Profit rate }}{\text { Total cost }}
$$

Data analysis method. In order to answer the research objectives that have been formulated, the data analysis method used is quantitative analysis obtained by tabulating and computed then analyzed using analysis of variance (ANOVA) according to the latin square design (LSD) to determine the effect of treatment (Steel and Torrie, 1993 ).

\section{RESULTS AND DISCUSSION}

The average consumption and nutrient digestibility of fattening Bali cows is shown in Tables 3 and 4 as follows.

Table 3 - Average nutritional consumption of fattening Bali cattle

\begin{tabular}{lllll}
\hline \multirow{2}{*}{ Parameter } & \multicolumn{3}{l}{} & \\
\cline { 2 - 5 } & $\mathrm{P}_{0}$ & $\mathrm{P}_{1}$ & $\mathrm{P}_{2}$ & $\mathrm{P}_{3}$ \\
\hline $\mathrm{KBK}(\mathrm{g} / \mathrm{e} / \mathrm{h})$ & $3.753,92$ & $3.826,24$ & $3.989,14$ & $3.808,53$ \\
$\mathrm{KBO}(\mathrm{g} / \mathrm{e} / \mathrm{h})$ & $2.712,33$ & $3.076,63$ & $3.203,09$ & $3.049,11$ \\
$\mathrm{KPK}(\mathrm{g} / \mathrm{e} / \mathrm{h})$ & 630,21 & 653,4 & 687,42 & 644,46 \\
$\mathrm{~K}$. Energi $(\mathrm{kkal} / \mathrm{e} / \mathrm{h})$ & $13.963,03$ & $14.313,66$ & $14.909,19$ & $14.173,52$ \\
\hline
\end{tabular}

Source: Primary Data (2020)

Based on Table 3, it shows that the consumption of dry matter, organic matter, crude protein of fattening Bali cattle was achieved in $\mathrm{P}_{2}$ treatment (concentrate contains $40 \%$ banana corm meal) and the lowest is in the $P_{0}$ treatment (concentrate without banana corm meal).

Table 4 - Average nutritional digestibility of fattening Bali cattle

\begin{tabular}{lllll}
\hline \multirow{2}{*}{ Parameter (\%) } & \multicolumn{2}{l}{ Treatment } & $\mathrm{P}_{2}$ & $\mathrm{P}_{3}$ \\
\cline { 2 - 5 } & $\mathrm{P}_{0}$ & $\mathrm{P}_{1}$ & 74.47 & 70.92 \\
KCBK & 68.89 & 71.37 & 72.99 & 68.79 \\
KCBO & 66.8 & 68.93 & 73.54 & 69.02 \\
KCPK & 70.01 & 71.23 & 74.03 & 69.9 \\
KC. Energy & 67.21 & 70.04 & & 73 \\
\hline
\end{tabular}

Source: Primary Data (2020).

Based on Table 4, it shows that the digestibility of dry matter, organic matter, crude protein of fattening Bali cows was achieved in $\mathrm{P}_{2}$ treatment (concentrate contains $40 \%$ banana corm meal) and the lowest is in the $\mathrm{P}_{0}$ treatment (concentrate without banana corm meal). The effect of providing concentrate feed supplementation containing fermented banana corm meal at different levels with $Z n$-biocomplex additives on the economic performance of Bali cattle can be seen in Table 5.

The effect of treatment on Bali cattle production costs. Production costs are a number of costs incurred in a livestock business to produce a product. These costs consist of fixed cost and variable cost or variable cost. Fixed costs are cost incurred for production facilities and can be used many times. These fixed costs include business land, pens, equipment used, and transportation facilities (Siregar, 2008). Variable costs are the cost incurred repeatedly, which include, among others, the cost of feed, labor wages, depreciation of cages, depreciation of equipment, medicines, vaccinations, and other costs in the form of electricity costs, donations, business taxes and fees. 
Table 5 - Average economic performance of fattening Bali cattle

\begin{tabular}{|c|c|c|c|c|c|}
\hline \multirow[b]{2}{*}{ Parameter (IDR) } & \multicolumn{4}{|l|}{ Treatment } & \multirow[b]{2}{*}{ P-Value } \\
\hline & $\mathrm{P}_{0} \pm \mathrm{SD}$ & $P_{1} \pm S D$ & $\mathrm{P}_{2} \pm \mathrm{SD}$ & $\mathrm{P}_{3} \pm \mathrm{SD}$ & \\
\hline Cost & $\begin{array}{l}5833750 \pm \\
71107.31^{a}\end{array}$ & $\begin{array}{l}5523750 \pm \\
87118.21^{b}\end{array}$ & $\begin{array}{l}5375000 \pm \\
88975.65^{b}\end{array}$ & $\begin{array}{l}5168750 \pm \\
55433.89^{b}\end{array}$ & $3.4 \mathrm{E}-07$ \\
\hline Income & $\begin{array}{l}6851250 \pm \\
93128.49^{a}\end{array}$ & $\begin{array}{l}7001250 \pm \\
167947.16^{a}\end{array}$ & $\begin{array}{l}7518750 \pm \\
87500^{\mathrm{b}}\end{array}$ & $\begin{array}{l}7413750 \pm \\
194738.07^{b}\end{array}$ & 5.9E-05 \\
\hline Profit & $\begin{array}{l}1017500 \pm \\
82209.08^{\mathrm{a}}\end{array}$ & $\begin{array}{l}1477500 \pm \\
233862.49^{b}\end{array}$ & $\begin{array}{l}2143750 \pm \\
139006.89^{c}\end{array}$ & $\begin{array}{l}2245000 \pm \\
1190000^{c}\end{array}$ & $7.44 \mathrm{E}-07$ \\
\hline Feed cost & $\begin{array}{l}751250 \pm \\
191588.75^{a}\end{array}$ & $\begin{array}{l}723750 \pm \\
68965.57^{\mathrm{a}}\end{array}$ & $\begin{array}{l}689655.7 \pm \\
88975.65^{\mathrm{b}}\end{array}$ & $\begin{array}{l}418750 \pm \\
55433.89^{c}\end{array}$ & $1 \mathrm{E}-06$ \\
\hline IOFC & $\begin{array}{l}266250 \pm \\
169576.67^{\mathrm{a}}\end{array}$ & $\begin{array}{l}753750 \pm \\
264303.33^{\text {b }}\end{array}$ & $\begin{array}{l}1518750 \pm \\
216386.03^{\mathrm{c}}\end{array}$ & $\begin{array}{l}1826250 \pm \\
201054.51^{\mathrm{c}}\end{array}$ & $1 \mathrm{E}-05$ \\
\hline BCR & $1.17 \pm 0.01^{a}$ & $1.27 \pm 0.05^{b}$ & $1.40 \pm 0.03^{\mathrm{c}}$ & $1.43 \pm 0.04^{\mathrm{C}}$ & 1E-07 \\
\hline
\end{tabular}

Note: different superscripts on the same line show a very significant effect $(P<0.01)$

Table 5 shows that the highest production cost was achieved by Bali cattle receiving $P_{0}$ treatment (IDR 5,833,750), then $\mathrm{P}_{1}$ treatment (IDR 5,523,750), $\mathrm{P}_{2}$ treatment (IDR 5,375,000) and the lowest was $P_{3}$ treatment (IDR 5,168.750). The results of the analysis of variance showed that the provision of concentrate feed supplementation containing fermented banana corm meal at different levels with Zn-biocomplex addition had a very significant effect $(P<0.01)$ on the production costs of fattening Bali cattle. The results of Duncan's test showed that $P_{0}-P_{1} ; P_{0}-P_{2} ; P_{0}-P_{3}$ were significant differences $(P<0.05)$, whereas between $P_{1}-P_{2}, P_{1}-P_{3}$, and $P_{2}-P_{3}$ showed no significant differences $(P>0.05)$. This indicates that the addition of banana corm meal to concentrate feed significantly reduces production costs. The low production costs in the $\mathrm{P}_{1}, \mathrm{P}_{2}$ and $\mathrm{P}_{3}$ treatments were due to the addition of fermented banana corm meal in the concentrate at different levels, causing lower ration prices. The lower the ration cost, the lower the production cost. In line with the opinion of Tumober et al., (2014) which states that production costs consist of feed costs, labor costs and the cost of medicines or vaccines.

The effect of treatment on Bali cattle income. Income shows the success of a business. The higher the income indicates that the business is more successful, the income is obtained from the reduction between revenue and costs. The term income is intended for people's livestock businesses, namely by using the cash flow method, which is an analysis method that only takes into account the costs that are actually spent in cash. According to Darmawi (2011) Net farm income or net farm income is the difference between total farm expenditure and gross farm income. Likewise, farm net cash flow or cash income is the difference between livestock business cash expenses and livestock business cash receipts.

Table 5 shows that the highest income was achieved by Bali cows who received $P_{2}$ treatment (IDR 7,518,750), then $P_{3}$ treatment (IDR 7,413,750), $P_{1}$ treatment (IDR 7,001,250), and the lowest was $P_{0}$ treatment (IDR 6,851,250). This difference was due to differences in the dry matter digestibility of the ration, where in this study the highest dry matter digestibility (DM) was obtained by treatment $P_{2}(74.47 \%)$ and the lowest was obtained by treatment $P_{1}$ (71.37\%) can be seen in Table 4 , so that the daily weight gain of cows that received $\mathrm{P}_{2}$ treatment was higher than other treatments which resulted in a different income. This is in accordance with the opinion of Purwanti et al., (2014) which states that one of the factors that influence livestock body weight gain is the quality of feed in terms of nutrition. Handayanta, et al., (2017) added that livestock growth is influenced by the type of livestock, age, phase (growth, maturity, pregnant, lactating).

The results of the analysis of variance showed that the provision of concentrated feed supplementation containing fermented banana corm meal at different levels with $\mathrm{Zn}$ biocomplex addition had a very significant effect $(\mathrm{P}<0.01)$ on the income of fattening Bali cows. The results of Duncan's test showed that; $P_{0}-P_{2} ; P_{0}-P_{3}, P_{1}-P_{2}$, and $P_{1}, P_{3}$ were significant differences $(P<0.05)$, whereas between $P_{0}-P_{1}, P_{2}-P_{3}$ showed no significant differences $(P>0.05)$. This shows that the supplementation of concentrate feed containing fermented banana corm meal at different levels significantly increases the income of the fattening cattle breeders. This is in accordance with the opinion of Triana et al., (2007) which 
states that the difference in income obtained from each treatment is due to the size of the income from each treatment as seen from the amount of production produced and the price of the product.

The effect of treatment on Bali cattle profit. Prawirokusumo (1990) states that profit or profit is the amount of rupiah obtained from the net income of a business. The result of the deduction from income and expenses incurred is the result of profit or loss. The profit earned is the result of the sale of beef cattle minus the costs incurred during the production period. This is in line with the statement of Daniel (2002), which states that at the end of each harvest the farmer will calculate the gross yield he gets. The results must be reduced by the costs incurred. After deducting all these costs, the farmer gets what is called the net yield or profit. If the value of the income obtained is positive, it can be said that the business is making a profit. Meanwhile, if it is negative, the business will suffer a loss.

Table 5 shows that the highest profit was obtained by cows receiving $\mathrm{P}_{0}$ treatment (IDR $1,017,500$ ), followed by $P_{1}$ (IDR 1,477,500), $P_{2}$ (IDR 2,143,750) and the lowest was $P_{3}$ (IDR $2,245,000)$. The difference in profits obtained by farmers varies due to the different ration costs in each treatment and the final weight of the livestock at the time of sale. The advantage of feeding concentrate with fermented banana corm meal $+100 \mathrm{mg} \mathrm{Zn-}$ biocomplex in the ration is obtained from selling the live weight of the livestock minus production costs. The results of the analysis of variance showed that the provision of concentrate feed supplementation containing fermented banana corm meal at different levels with $\mathrm{Zn}$-biocomplex additive had a very significant effect $(\mathrm{P}<0.01)$ on the profit of selling cattle. This sales profit is due to the different income earned from each treatment. Even though the nominal benefits obtained are different, all treatments provide benefits. The Duncan test results show that $P_{0}-P_{1} ; P_{0}-P_{2} ; P_{0}-P_{3}, P_{1}-P_{2}$, and $P_{1}-P_{3}$ were significant differences $(P<0.05)$, whereas between $P_{2}-P_{3}$ showed no significant differences $(P>0.05)$. This result may occur because the cost of revenue in the cattle fattening business is greater than the costs incurred and the amount of profit is influenced by the final weight of the cattle. The heavier the livestock, the greater the revenue obtained, while the amount of profit is also influenced by the amount of input costs used in the production process. This is in accordance with the opinion of Jefferies (2007) which states that structural price changes can also change production methods, the use of quality production inputs and an increase in the number of inputs can change the selling price of cattle which can lead to high profits. Furthermore, Malole et al., (2014) stated that the length of time for fattening had a significant effect on profits. Mohammed et al., (2013) added that the length of time to maintain and the cost of buying cattle has a significant effect on profitability.

The effect of treatment on Bali cattle costs. The costs of feed are the total cost allocated by the farmer for Bali cattle feed in a certain period of time. Most of the feed expense is used for the purchase of concentrate. This is because forage is obtained by grazing so that feed costs can be minimized. Otampi et al., (2017) stated that the cost of feed is the biggest cost in beef cattle business. Table 5 shows that the highest cost of feed was obtained by Bali cows receiving $P_{0}$ treatment (IDR 751,250), followed by $P_{1}$ (IDR 723,750), $\mathrm{P}_{2}$ (IDR 689,655.7), and the lowest $\mathrm{P}_{3}$ (IDR 418,750). The results of the analysis of variance showed that the provision of concentrate feed supplementation containing fermented banana corm meal at different levels with Zn-biocomplex addition had a very significant effect $(P$ $<0.01$ ) on the cost of feed. This is because the level of concentrate feed supplementation containing fermented banana corm in the ration is different for each treatment. If it is seen in Table 5, the cost of feed has decreased along with the increase in the level of giving the concentrate containing fermented banana corm meal; while the highest cost is the treatment without the addition of concentrate. The results of Duncan's test showed that P0-P2; P0-P3, P1-P2, P1-P3, P2-P3 were significant differences $(P<0.05)$, whereas between $P 0-P 1$ showed no significant differences $(P>0.05)$. This shows that supplementation of concentrate feed containing meal from banana corm waste can reduce feed costs. This condition is in accordance with the opinion of Subekti (2009) which states that the use of local potential is the best choice for obtaining cheap feed prices. 
The effect of treatment on income over feed cost of Bali cattle. Income over feed cost (IOFC) is the difference between revenue and feed costs (Mayulu et al., 2009). Revenue is the multiplication of livestock production or daily weight gain $(\mathrm{PBBH})$ with the selling price, while the cost of feed is the cost incurred to produce livestock body weight gain (Prasetiyo, 2013). IOFC is a concept to determine business analysis as an early indicator of beef cattle fattening in the short term (Muyasaroh et al., 2015). IOFC calculations are carried out to determine the economic value of feed on beef cattle income. IOFC is carried out because the cost of feed ranges from $60-80 \%$ of the total product cost (Astutik et al., 2002). Table 5 shows the IOFC value of each treatment given to fattening Bali cattle. From Table 5 , it is known that the highest IOFC value was achieved by P3 treatment (IDR 1,826,250), followed by P2 treatment (IDR 1,518,750), P1 treatment (IDR 753,750), and the lowest was P0 treatment (IDR 266,250). IOFC values were sought to determine which rations were effective at increasing livestock productivity at the lowest price.

The results of the analysis of variance showed that the provision of concentrated feed supplementation containing fermented banana corm meal at different levels with added $\mathrm{Zn}$ biocomplex had a very significant effect $(P>0.05)$ on IOFC. The Duncan test results show that $P_{0}-P_{1} ; P_{0}-P_{2} ; P_{0}-P_{3}, P_{1}-P_{2}, P_{2}-P_{3}$ were significant differences $(P<0.05)$, whereas between $P 2-P 3$ showed no significant differences ( $P>0.05$ ). This causes the resulting IOFC value to be different in each treatment. The numerical IOFC value increased along with the level of addition of fermented banana corm meal $+100 \mathrm{mg}$ Zn-biocomplex in concentrate feed which caused the ration price to decrease. This is in accordance with the opinion of Purwanti et al., (2014) which states that the income analysis using the IOFC method is calculated based on the feeder purchase price, the selling price of cattle and the cost of rations during maintenance. Furthermore, Zakiatulyaqin et al., (2017) stated that IOFC is calculated because $\geq 70 \%$ of production costs come from feed so it can be seen whether the ration used is economical or not.

The effect of treatment on the benefit cost ratio of Bali cattle. Business analysis is a very important approach for a livestock business. Business analysis is carried out to determine whether a business is feasible to develop or not, seen from the marketing and production aspects. The business analysis used in this study to assess business feasibility is the Benefit cost ratio (BCR). BCR is a comparison between the present value of benefits and the present value of costs, so that BCR shows the benefits obtained for every additional one rupiah of expenditure. Table 5 shows that the highest BCR is $P_{3}(1.43)$, followed by $P_{2}(1.40)$, $P_{1}$ (1.27) and the lowest is $P_{0}$ (1.17).

The results of the analysis of variance showed that the provision of concentrate feed supplementation containing fermented banana corm meal at different levels with $\mathrm{Zn}$ biocomplex additive had a very significant effect $(P<0.01)$ on the BCR of cows. The Duncan test results show that $P_{0}-P_{1} ; P_{0}-P_{2} ; P_{0}-P_{3}, P_{1}-P_{2}, P_{2}-P_{3}$ were significant differences $(P<0.05)$, whereas between $P_{2}-P_{3}$ showed no significant differences $(P>0.05)$. This is because the costs incurred for each treatment are different. Table 5 shows that the BCR value of each treatment is more than 1 . In the $P_{0}$ treatment the $B C R$ value is 1.17 , which means that for every IDR 1,000 costs incurred, the treatment will result in a gain or benefit of 1.17. In the $P_{1}$ treatment, the BCR value is 1.27 , which means that for every Rp. 1,000, - costs incurred, the treatment will result in a gain or benefit of 1.27; while in $\mathrm{P}_{2}$ treatment the $B C R$ value is 1.40 , which means that for every IDR 1,000 costs incurred, the treatment will result in a gain or benefit of 1.40; and in the $\mathrm{P}_{3}$ treatment the $B C R$ value is 1.43 , which means that for every $R p$. 1,000 , - costs incurred, the treatment will result in a gain or benefit of 1.43. The BCR value in the results of this study provides benefits and is feasible to run. This is in accordance with the opinion of Zulfanita et al., (2009) which states that a business is said to be feasible and provides benefits if the BCR value is greater than 1 (BCR> 1). The greater the BCR value obtained, the greater the benefits to be obtained from each treatment in the cattle fattening business. This is the same as the opinion of Arief et al., (2018) which states that the higher the BCR value, the higher the benefits. 


\section{CONCLUSION}

The conclusion in this study is that concentrate feed supplementation containing fermented banana corm at different levels with $\mathrm{Zn}$-biocomplex addition significantly affects the economic performance of Bali cattle fattening.

\section{ACKNOWLEDGEMENTS}

The authors wish to acknowledge the Ministry of Research and Technology/National Research and Innovation Agency (RISTEK/BRIN) for providing the funding for this research through the 2020 national competitive grants through applied research scheme.

\section{REFERENCES}

1. Arief F., N. Hariyani., Soeharsono., W. P. Lokapirnasari., M. Lamid., and A. A. Arif. 2018. Analisis kelayakan and manajemen uaha peternakan sapi perah penerima kredit simpan pinjam di Koperasi SAE Pujon. Jurnal IImu and Teknologi Peternakan Tropis.6 (3): 327333.

2. Astutik, S. I. B., M. Arifin., and W. S. Dilaga. 2002. Respon sapi PO berbasis pakan jerami padi terhadap berbagai formula "urea molases block". Seminar Nasional Teknologi Peternakan and Veteriner. Fakultas Peternakan, Universitas Diponegoro. Semarang.

3. Daniel, M. 2002. Pengantar Ekonomi Pertanrian Untuk Perencanaan. Univesrsitas Indonesia Press, Jakarta.

4. Darmawi, D. 2011. Pendapatan usaha pemeliharaan sapi Bali di kabupaten muaro jambi. Jurnal IImiah IImu Peternakan. 14 (1): 14-22.

5. Handayanta E, Lutojo, K Nurdiati. 2017. Efisiensi produksi sapi potong pada peternakan rakyat pada musim kemarau di daerah pertanian lahan kering kabupaten gunung kidul. Caraka Tani: Journal of Sustainable Agriculture. 32 (1): 49-54.

6. Jeferies, K. 2007. The Impact of Cattle/Beef Prices On Income And Peverti In Botswana. Southern Africa Gaborone. Botswana.

7. Malole, J. L., R. J. M Kadigi., and A. Z. Sangeda. 2014. Cost and benefits of beef cattle fattening schemes some selected areas of North West Tanzania. Iranian Journal of applied Animal Science. (4): 669-706.

8. Mayulu, H., B Suryanto, Sunarso, M. Christiyanto, F. I. Ballo and Refa'i. 2009. Feasibility of Complete Feed Based on Ammonitiated Fermented Rice Straw Utilization on the Beef Cattle Farming. J. I. Tropic. Anim. Agri. 34 (2): 74-78.

9. Mohammed. S., I. Mhammed., and I. Adamu. 2013. Socioeconomic factors influencing profitability of cattle marketing in Gombe Metropolis, Nigeria. International Journal of scientific and teknology research. 2 (12): 288-292.

10. Muyasaroh. S., I. G. S. Budisatria., and Kustantinah. 2015. Income over feed cost for bef cattle fattening by sarjana membangun desa (SDM) in bantul and sleman district. Buletin Peternakan. 39 (3): 205-211.

11. Otampi R. S., F. H. Elly., M. A. V. Manese., G. D. Lenzun. 2017. Pengaruh Harga Pakan and Upah Tenaga Kerja Terhadap Usaha Ternak Sapi Potong Petani Peternak di Desa Wineruh Kecamatan Likupang Timur Kabupaten Minahasa Utara. Jurnal Zootek. 37 (2): 483-495.

12. Paulus C. A., Pellokila M. R., Azmanajaya E., 2018 Local community institutions for sustainable creative and productive enterprises in the border region of Indonesia - Timor Leste in Belu district. Russian Journal of Agricultural and Socio-Economic Sciences 83(11):75-83.

13. Paulus C. A., Pellokila M. R., Sobang Y. U. L., Azmanajaya E., 2019 The alternative livelihood development strategy in order to improve local fishermen revenue in the border region of Indonesia and Timor Leste. AACL Bioflux 12(1):269-279.

14. Paulus C. A., Sobang Y. U. L., Azmanajaya E., Pellokila M. R., Henuk Y. L., 2020 Management strategies for leading sectors of fisheries, livestock and agriculture 
resources in supporting the economic of border household in the border between Indonesia and Timor Leste. IOP Conference Series: Earth and Environmental Science 454(1):012063.

15. Paulus C. A., Sobang Y. U. L., Pellokila M. R., Azmanajaya E., 2018 The sustainability development status of pigs livestock on traditional fishery household in Nembrala village of Rote Ndao Island. Russian Journal of Agricultural and Socio-Economic Sciences 76(4):315-322.

16. Paulus, C. A., Azmanajaya, E., Pellokila, M. R., \& Paranoan, N. (2020). Prospective strategies for sustainable local economic development in support of the SDGs' goals "inclusive and sustainable economic growth" in the border region of Indonesia- Timor Leste, Belu Regency, East Nusa Tenggara, Indonesia. JPhCS, 1464(1), 012053.

17. Prasetiyo, A. B. 2013. Partisipasi Pelaksanaan Program Sarjana Membangun Desa dalam Pengembangan Sapi Potong di Kabupaten Bantul Daerah Istimewa Yogyakarta. Tesis Fakultas peternakan, Universitas Gadjah Mada, Yogyakarta.

18. Prawirokusumo, S. 1990. Ilmu Usaha Tani. BPFE. Yogyakarta.

19. Purwanti D, Suryahadi, EvvyernieD.20 14. Performa sapi potong sebagai respon dari suplementasi probiotik padat and cair. Buletin Makanan Ternak IPB. 101 (1): 13-24.

20. Rosdiana., R. 2009. Pemanfaatan Limbah dari Tanaman Pisang. Bharatara Karya Aksara,Jakarta.

21. S Fattah, G. A. Y. Lestari, B. Sabtu, Y. U. L. Sobang, G. Maranata and F. D Samba. 2019.Technical and Economic Value of the Use Ration for Male Fattening Bali Cattle Farmers Patterns with Supplementation Complete Feed Containing Silage Banana Stems. IOP Conf. Series: Earth and Environmental Science 372 (2019) 012028 IOP Publishing doi:10.1088/1755-1315/372/1/012028

22. Siregar S. B. 2002. Ransum Ternak Ruminansia. PT Penebar Swadaya, Jakarta.

23. Sobang Y. U. L., Maranatha G., Paulus C. A., Basuki T., 2020 Community adaptation strategy affected by Covid 19 pandemic in the fulfilling of family food. AES Bioflux 12(2):170-177.

24. Sobang, Y. U. L, M. Yunus, Tenang, G. Maranatha, F. D Samba, and Y. L. Henuk. 2020. Analysis of concentrated nutrition with banana starch tuber meal fermented with Zn bio complex as a feed additive fed to beef cattle. IOP Conf. Series: Earth and Environmental Science 454 (2020) 012061 IOP Publishing doi:10.1088/1755-1315/454/1/012061.

25. Sobang., Y. U. L. 2005. Karakteristik sistem penggemukan sapi pola gaduhan menurut zona groklimat and dampaknya terhadap pendapatan petani di Kabupaten Kupang NTT. Bulletin Nutrisi Fapet Undana.

26. Soekartawi. 2002. Analisis usahatani. UI Press. Universitas Indonesia.

27. Steel R.G.D and J.H. Torrie. 1993. Prinsip and Prosedur Statistika. Gramedia Pustaka Utama. Jakarta

28. Subekti, E. 2009. Ketahanan Pakan Ternak Indonesia. Mediagro. 5 (2): 63-71.

29. Triana A., T. Salam., M. Muis. 2007. Analisis pendapatan usaha peternakan ayam ras Petelur periode layer di kecamatan cenrana kabupaten maros. Jurnal Agrisistem. 3 (1): 11-15.

30. Tumober, J. C., A. Makalew., A. H. S. Salendu., and E. K. M. Endoh. 2014. Analisis keuntungan pemeliharaan sapi di kecamatan suluun tareran kabupaten minahasa selatan. Junal Zootek. 34 (2): 18-26.

31. Venkatesh R, Krishna V, Girish Kumar K, Pradeepa K, Santosh Kumar SR. 2013 Antibacterial activity of ethanol extract of Musa paradisiaca cv. Puttabale and Musa acuminate cv. Grand Naine. Asian Journal of Pharmaceutical and Clinical Research. 6 (2): 169-172.

32. Zakiatulyaqin., I. Suswanto., R. B. Lestari., D. Setiawan., and A. M. S. Munir. 2017. Income over feed cost and $\mathrm{R}-\mathrm{C}$ ratio usaha ternak sapi melalui pmanfaatan limbah kelapa sawit. Jurnal ilmiah peternakan terpadu. 5 (1): 18-22.

33. Zulfanita., M. A. Wiguna., and S. Nurtini. (2009). Evaluasi kelayakan uaha penggemukan sapi potong gaduhan di desa grantung kecamatan bayan kabupaten purworejo. Buletin Peternakan. 33 (1): 57-63. 